\title{
The rise of the private sector in fragmentary planning in England
}

Article

Accepted Version

Parker, G., Street, E. and Wargent, M. (2018) The rise of the private sector in fragmentary planning in England. Planning Theory and Practice, 19 (5). pp. 734-750. ISSN 1464-9357 doi: https://doi.org/10.1080/14649357.2018.1532529 Available at https://centaur.reading.ac.uk/79652/

It is advisable to refer to the publisher's version if you intend to cite from the work. See Guidance on citing.

To link to this article DOI: http://dx.doi.org/10.1080/14649357.2018.1532529

Publisher: Taylor and Francis

All outputs in CentAUR are protected by Intellectual Property Rights law, including copyright law. Copyright and IPR is retained by the creators or other copyright holders. Terms and conditions for use of this material are defined in the End User Agreement.

\section{www.reading.ac.uk/centaur}

\section{CentAUR}

Central Archive at the University of Reading

Reading's research outputs online 


\section{Author Biographies}

Gavin Parker is Professor of Planning Studies at the University of Reading, UK. His research centres on planning and land-use conflict in urban and rural areas and he has published extensively on citizenship and participation in planning.

Emma Street is Associate Professor in Planning and Urban Governance at the University of Reading, UK. Her research focusses on the planning, design, regulation and governance of urban space.

Matthew Wargent is British Academy Postdoctoral Research Fellow at the University of Reading, UK. His research centres on planning and local governance, in particular the role of non-state actors in local democratic settings.

\section{Funding}

The research discussed in this paper was supported by the University of Reading Research Endowment Trust Fund.

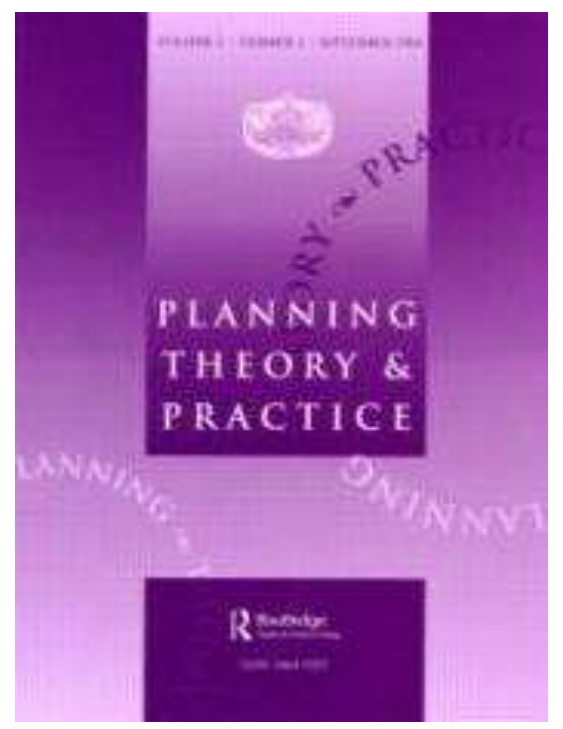




\title{
The Rise of the Private Sector in Fragmentary Planning in England
}

\author{
Planning Theory and Practice
}

Advance of publication version (Autumn 2018)

Gavin Parker g.parker@reading.ac.uk Department of Real Estate and Planning, University of Reading, Berkshire, UK

Emma Street - Department of Real Estate and Planning, University of Reading, Berkshire, UK

Matthew Wargent - Department of Real Estate and Planning, University of Reading, Berkshire, UK

\begin{abstract}
Over the past 30 years, the English planning system has undergone a series of reforms designed to increase efficiency, promote growth and, since 2010, achieve cost savings under the auspices of austerity. These reforms can be understood as part of a broader reorganisation of public services and functions in many Western democracies which have seen private sector providers move in to service new markets and take on functions previously delivered by public servants. Drawing on findings from research with key actors from both public and private sectors, this paper argues that the English planning system is increasingly fragmented, and task-oriented, and requiring of knowledge and skills-sets which local planning authorities typically do not possess. A relational shift regarding the (in)capacity of public planners and private sector actors drawn from a range of disciplinary backgrounds has occurred, with the latter now providing a wide range of inputs to the planning system, typically in the guise of consultants. While planning has long been an exercise in co-production, involving a number of different actors, there has been limited discussion of the role private sector actors play in servicing and reproducing the planning system. The paper therefore describes how 'fragmentary planning' has emerged in England, and reflects on the knowledges, skills and capacities the system now requires. In concluding, we outline the questions of governance that these dynamics raise, and suggest avenues of further research.
\end{abstract}

Keywords: planning; consultants; private sector; public sector; privatisation; knowledge; skills. 


\section{The Rise of the Private Sector in Fragmentary Planning in England}

\section{Introduction}

The private sector is now involved in virtually all aspects of the management of public life in the United Kingdom. The privatisation of public goods and services since the 1980s, pursued by successive governments from across the political spectrum, has featured a range of processes (defined below) including market opportunities for a wide and heterogeneous range of private sector organisations, and has blurred the lines between notions of 'public' and 'private'. The UK planning system has a long and substantial history of interaction with the private sector. Indeed prior to the Second World War, planning was largely the reserve of architect-planners, and, since the inception of the 1947 system - despite significant fluctuations in the size, nature and role of the consultancy market - private firms continued to be employed by both central and local government. Throughout this period, consultants have acted as agents for private interests and actors. However since the late 1990s, the nature of consultant use by the public sector appears to have changed, with private firms having expanded in both scale and scope and increasingly involved in all aspects of planning practice.

This paper argues that there are three central reasons for this shift. First, the wider transition from government to governance has precipitated a move towards partnership working and coproduction ${ }^{1}$ in public services, drawing in a range of non-state actors. Second, reductions in public sector budgets have created gaps in capacity, knowledge and skills - particularly in local government - that the private sector has been able to fill. Third, frequent and on-going reforms to planning policy and legislation have expanded the traditional remit of planning, creating operational complexity and prompting the re-organisation of the sector. The result is that the English planning system ${ }^{2}$ is increasingly fragmented, complex and task-oriented in nature. The system now requires new or at least differently configured forms of knowledge inputs and skills, many of which cannot be readily serviced from within Local Planning Authorities (LPAs). As a result, a wide range of private sector consultancies from global multi-sector organisations through to sole practitioners, have emerged in order to service these requirements (Raco, 2018), from producing applied research and evidence underpinning planning policy to undertaking wholesale

\footnotetext{
${ }^{1}$ A widely-used term, here we deploy co-production in a broad sense to reflect the sharing of resources (capacity, knowledge, skills, influence and so on) between disparate parties - in this instance public and private sector actors involved in planning practice - where both sides make substantial contributions in a process of joint working in order to achieve certain (either open-ended or pre-defined) ends. Following Watson's (2014: 63) this can serve to "deepen the pot" from which planning ideas can be drawn and thereby potentially expand the scope of planning thought. In the context of this paper, we consider co-production as an instrumental means to specific ends but also as representing the alteration of on-going practices underlying public/private relations.

2 Since 1998, certain planning functions have been devolved to the Scottish, Welsh and Northern Irish governments. This accounts for the variation in our use of 'UK' and 'English' planning respectively.
} 
development management services. This operational context has intensified in the past decade, however, what we term 'fragmentary planning' has had a much longer gestation period that is connected to the dominance of neoliberal thinking and policy responses in the English context since the early 1980s (e.g. Shaw and Lord, 2007; Allmendinger and Haughton, 2013).

Despite the unprecedented level of private sector involvement in the operation of the planning system, planning activity, both in England and elsewhere, is still widely regarded as a predominantly public sector activity. In this paper we challenge this view, by documenting how this change has occurred and raising critical points of reflection arising from contemporary planning practice. While the focus is on the English planning system, given the way in which this is (often problematically) held up as a system to replicate elsewhere, our analysis has wider resonance for planning practice globally. For example, in the US Loh and Norton (2013) indicated that consultants were felt to have 'nearly identical values' to those of public officials, allowing both parties to remain optimistic about underlying planning values. The study argued that consultant use could supplement in-house staff, provide flexibility, and add technical expertise, outweighing the potential disadvantages of higher costs (to the public purse) and a lack of local knowledge. Later research by the same authors, however, found that consultant use "does indeed appear to have a substantial effect on the policy focus of plans" (Loh and Norton, 2015: 207), although this appeared to be more a question of degree than substantive policy change. This raises questions about the type of consultants' impact on the legitimacy of the planning process and on accountability, but also the 'upstream' drivers that lead to the consultant use in the first instance.

This paper is structured as follows: first, we discuss the contexts through which the fragmentary planning has emerged. Second, we consider the requirements that the current system places upon planning knowledges, skills and capacities, and the consequences in terms of the relative balance of inputs from public and private sector planners. This is illustrated using data collected as part of a study of consultant use in local plan-making, a statutory function of English LPAs. Finally we reflect on some of the challenges and opportunities linked to the operational realities of this fragmentary planning and set out a thematic agenda for further research.

\section{The Emergence of Fragmentary Planning in England}

Since its inception in 1947, the UK planning system has undergone successive rounds of reform, as governments of all stripes have sought to make it 'fit for purpose'. Since (at least) the Planning Advisory Group's report of 1965, the rhetoric of reform has been laced with concern for planning delay and coincidental need for 'efficiency'. With Margaret Thatcher's second term (1983-1987), 
the discourse of planning reform continued to concentrate on efficiency, but also to constrict planning's ambit, with the system to become more flexible, 'market-orientated' and better able to 'deliver growth'. Following the election of the first New Labour administration in 1997, a rhetoric of modernisation came to dominate the reform agenda, with the rise of spatial planning and a particular emphasis on evidence-based policy (see Davoudi, 2006). Further calls for systemic reform to the planning system were apparent in the run-up to the 2010 election (Conservative Party, 2009; 2010) and subsequently informed the Conservative-Liberal Democrat Coalition's approach to planning (2010-2015). Following the election of a majority Conservative government in 2015, appetite for delivering 'system change' shows little sign of abating, with various policy changes discussed and legislative amendments undertaken. This environment has acted to sustain a process of change in planning that is complex and multi-faceted (Higgins and Allmendinger, 1999; Shaw and Lord, 2007; Lord and Tewdwr-Jones, 2014; MacDonald et al., 2014; Parker et al., 2018).

Since 2010, and in the wake of the Global Financial Crisis of 2008 and subsequent dominance of the politics of austerity, the rhetoric of necessary reform to planning in England has been bound up with significant public sector budget reductions. Spending cuts have fallen particularly hard on local government services, including cuts of up to $40 \%$ to local government planning services and over a third of staff being cut in the period 2011-2015 (RTPI, 2015a). This has predictably produced a capacity gap in local authorities, which contrasts with capacity growth in the private sector. This points to an absolute and relative decline in capacity in the public sector, whether in terms of functions and tasks that were previously handled 'in-house' by LPAs, or tasks that were not previously part of the formal planning process. The result has been that tasks are increasingly outsourced to private sector consultancies.

However, the increasing role for the private sector is more than a neat, unidirectional transfer of roles and responsibilities, but should be understood as a relational, co-emergent and contingent process (see Figure 1 below). That is, changes within the planning profession, the morphing of public capacity, on-going reconfiguration of the consultant market, and regulatory change in a neoliberal and fragmentary context, act to influence each other and produce new constellations of relations which remain poorly understood.

Concurrent with spending cuts in the name of austerity, the introduction of the National Planning Policy Framework (DCLG, 2012) sought to allow "people and communities back into planning ... [b]y replacing over a thousand pages of national policy with around fifty, written simply and clearly" (DCLG, 2012: ii). This has set the tone for the operational environment, with central government critiquing how 'elaborate and forbidding' planning had supposedly become (DCLG, 2012: i). A similar tone accompanied the Localism Act (2011) which devolved limited planning powers to 
communities through new initiatives such as Neighbourhood Planning, while also opening up new streams of work for private consultancies (Parker et al., 2015). As with the wider planning system, here too there has been little consideration of how private sector actors feature in new partnership arrangements with other actors. This is despite a long term process of outsourcing of responsibilities and in-sourcing of expertise in public planning functions dating back to the Schuster Committee of 1950 (see Fordham, 1990; Higgins and Allmendinger, 1999; Lord and Tewdwr-Jones, 2014; MacDonald et al., 2014). More recently, this process has been closely associated with an ideological shift away from state-led planning and towards markets which involve pressure being placed on local government to retrench and deliver variations of 'marketorientated' (under the New Right) planning or 'best value' (under New Labour) and enhanced performance (see Ascher, 1987; Thornley, 1993; Shaw and Lord, 2007; Haughton et al., 2009).

Ironically however, reformist discourses of speeding-up and simplifying planning has fed an extensification of English planning - by which we mean a widening of planning's ambit at a time of reduced financial resources. Concurrently, numerous changes to planning policy and legislation have created a compartmentalisation effect whereby planning practice is broken down into a series of discrete (and therefore 'deliverable') tasks (Raco et al., 2016; Raco, 2018), many of which lay outside of traditional or core planning practices. For example, the NPPF (DCLG, 2012: 42) identified the need for planners to pay 'careful attention to viability and costs in plan-making and decision-taking'. In practice, this meant that the use of development viability appraisals - a valuation tool used to establish the level at which development schemes become economically worthwhile for developers - has become commonplace. In this way, a significant amount of planning practice has become increasingly focused on the fulfilment of such specific, bounded tasks, many of which are carried out by planning consultants or indeed non-planners. Consequently, planning has become fragmentary. This does not suggest that planning was ever an entirely holistic or even comprehensive process, but that contemporary practice is increasingly marked by the parcelling-up and sharing-out of planning activity across tasks, sectors, professions, space and interests. Whether the overall sum of these parts creates synergy or inefficiency remains open to debate, however, what is evident is that the sum of planning's parts is not easily discernible. This is important since the stated purpose of planning is to help achieve sustainable development (e.g. DCLG, 2012: i; MHCLG, 2018a: 5): a broad-based and rather general goal that infers a need to consider a wide range of factors before reaching a synoptic and subjective judgement of 'sustainability'.

Many of the tasks created by the extensification of planning's ambit at a time of (local) government retrenchment are being serviced by the private sector (Parker et al., 2018). Justifications for private sector inputs include: increased capacity and efficiency; cost-effectiveness; specialised 
skills, knowledge and expertise; creative and visionary inputs; increased legitimacy; and increased independence and critical distance (Davoudi and Healey, 1990; Gunn and Vigar, 2012; Linovski, 2015; 2018), although it is worth noting that many of these attributes have also been problematised. Fragmentary planning requires a myriad of skills, knowledge and expertise, and many of the task-based inputs are predisposed towards the skills-sets of non-planners (or at least those beyond the core competencies that many public sector planning authorities typically possess). The discrete and deliverable elements of such a system appear to mirror private sector project management structures in which expertise is sold on the basis that it is directly targeted towards achieving specific outcomes and meeting particular client needs (see Davies and MacKenzie, 2014). The effect is an opening up of the planning process to inputs from a range of private companies who are adept at selling their ability to offer 'solutions' to specific issues as set out within the system (e.g. demonstrating viability, providing a retail impact study, or processing specific planning applications - see also Raco et al. (2013) on 'solutionism') and in so doing enter the realm of planning. This opens up both the planning profession to questions of expertise (i.e. what is the particular field of expertise that planners can lay claim to) and the planning system, to questions about the range of actors involved, their role and on-going influence, and who ultimately scrutinises the resultant outcomes.

None of the above is to suggest that the private sector's involvement in the English planning system is without precedent. There is a long and complex history of engaging private actors in planning in the UK, both before and after the Town and Country Planning Act (1947) which brought the majority of planning activity under local government control. What appears to have changed in recent decades is the scope and depth of private sector involvement in servicing, and even sustaining, the planning system. Today, private sector consultants are engaged in planning practice in three main ways: first acting as advocates for development sites on behalf of a developer client, or promoting a site for a landowner; second, as advisors providing information and acting under commission for LPA clients; and third, as scrutineers, assessing the quality and validity of various planning objects such as local and neighbourhood plans and planning applications. This role has emerged more recently as the private sector has created internal markets in development viability work and neighbourhood planning activity (Parker et al., 2015; 2017). Here, consultants acting under contract to LPAs (and at times to communities) are not only providing inputs to the planning system in the form of information or evidence, but are also acting to validate particular forms of planning knowledge in certain circumstances (Parker et al., 2018).

Therefore, consultants draw upon their specialist knowledge to make a number of technical, evidence-based inputs to the planning system and scrutinise the epistemic quality of such inputs and their effects on the wider operation of planning. The privatisation of planning therefore 
involves more than the servicing of particular niches or entailing more strategic inputs such as running core planning services (see Capita, 2016). It's important to note that many of the consultants involved are not trained, qualified or chartered planners, but come from a diverse set of professional backgrounds including: surveying, economic development, regeneration, architecture, environmental management, landscape architecture and heritage conservation. This reflects the range of tasks that are now part of formal planning's widened scope but which also mirror the long-standing recognition of the shifting, amorphous field of expertise that planning seeks to lay claim over.

Taken together, the three consultant roles described above mean that private actors are producing, managing and verifying a broad set of planning and planning-related knowledge for a wide range of input tasks. Planning scholars have been slow to recognise this. One reason for this may be the increased use of private sector consultants seen in other public sector functions and services during the same period. In this sense, a creeping privatisation of English planning has become, rather incrementally and unremarkably, normalised as part of the now familiar model of $21^{\text {st }}$ century public service delivery. Indeed, the UK has been seen as something of a pioneer of waves of public sector reform by other western democracies (Christensen and Laegreid, 2007). For example, elements of the current English planning system, such as the recently revised Permitted Development Rights package, have been replicated by administrations looking to deliver system change, which are often justified along lines of efficiency (Remoy and Street, 2018; Clifford et al., 2018).

These shifts have been perceived as motivated by an ideology that is antipathetic to planning as a state activity, with efficiency increasingly regarded as sine qua non at the expense of alternative rationales or governance goals (Clifford, 2016). The effects of the Global Financial Crisis and resultant austerity agenda pursued in the UK have intensified the search for system efficiency. Financial scarcity has been employed to justify the use of the reputedly more cost-effective private sector, reducing revenue expenditure whilst seeking to realise longer term shifts in local governance associated with evolving forms of New Public Management and subsequent iterations of public sector reform (see Christensen and Laegreid, 2007; Diefenbach, 2009; Lapsley, 2009). Such rationalities, whilst not new, have arguably precipitated an extensive series of reforms to the planning system. This has often been justified as a necessary step in creating a type of planning that is more conducive to growth and development (i.e. performance management and the introduction of time-dependent metrics) and yet also substantive regulatory change. For example; the introduction of strategic environmental assessments has simultaneously required a range of environmental considerations and other matters to be brought into formal plan-making. The former builds on a long-running and on-going critique that posits failures in the English system as 
preventing market actors from providing the type, speed and scale of development required. The latter acts to expand bureaucratic requirements that can only realistically be met by buying-in private sector expertise. Thus, while much of the post-2010 planning reforms have been expressed in the language of localism with the voluntary and community sector (VCS) mobilised in pursuit of refinements to the system, it is the efficiency gains which have remained a central goal of planning reform. Coupled with long-standing issues of insufficient capacity in the VCS, in practice the post-2010 reforms along with substantive changes to legal requirements in planning in the longer term have meant that private sector consultants are often best placed to service new system requirements. As Barnett (2005) and others have argued, processes of privatisation often follow an ironic pattern in so far as they are triggered by arguments against the rigidities of statist forms of public policy in the name of greater autonomy, equality, and participation - as Raco et al. (2016: 218) contend, new forms of localism have:

... opened up numerous opportunities for the mobilisation of expert knowledge and power, much of which is derived not from civil society but from the private sector ... Despite the rhetoric of co-production, pluralism, and localism seen in the planning field since the mid-1990s ... the structures surrounding development planning have been transformed into a delivery-focussed system that mimics the structures and functions of private-sector organisations.

The language of localism was preceded by a wider shift in the state's role from welfare state provider to market-orientated enabler. Coincidently, planning changed from a welfare state profession serving the public interest towards a skills-based profession delivering a serviceprovider/client model (Evans, 1995; Davoudi and Pendlebury, 2010) that has ushered in a more transnational form of planning practice. This alongside "the increasing role of the private sector in both development and planning activities", Davoudi and Pendlebury (2010: 632) note, has begun "to challenge the taken-for-granted place of planning in local government".

Shaw and Lord (2007), writing about the shifts in the New Labour era, have focussed on how change would be absorbed by the public sector while acknowledging how the role of local planning officers was shifting towards commissioning, managing and overseeing plan-making. The inputs of the private sector were downplayed there, but the assessment provides a clear indication of the wider direction of travel for the planning system towards one of co-production between public and private planners (and to some extent communities and the wider VCS). Such incremental shifts in roles and responsibilities present a wider question regarding privatisation and what it actually constitutes. Gunn (2018) highlights the distinction between commercialisation and marketisation as part of shifts towards privatization and the rise of the entrepreneurial state. Here, privatisation is taken to mean the passing of formerly public assets, services and competencies to private interests in either a wholesale or partial manner (i.e. including hybrid arrangements such as 
public/private partnerships or private finance initiatives). Within this there are a range of processes such as commodification (treating a good or service as something be bought and sold); marketisation (the exposure of an industry or service to market forces) and commercialisation (managing an industry or service principally for financial gain). These processes (of planning) and privatisation (of tasks) can act to produce subtle adjustments in tacit assumptions, problem frames, logics of procedure, and selectively accumulated knowledge that subsequently underpin future practice. Consequently, both the shaping of wider dispositions and the balance of responsibility are crucial to understanding more subtle variants of privatization as above.

The cycle of change caused by central government reform on a "near permanent basis, as incoming political administrations seek to modernise, reform or 'deregulate' planning" (Allmendinger and Haughton, 2015: 29) has placed private sector actors in a prime position to respond to the new needs given the inherent heterogeneity and therefore flexibility of the market. Recent changes have been introduced in quick succession, increasing the pressure on the planning system, and in particular on LPAs who are faced with time-sensitive targets around housing delivery in England (e.g. five year land supply targets) and in local plan production (as discussed below), but without the necessary resources or skills required. This has culminated in a recursive, multi-change environment set out in the four dimensions of Figure 1 depicting a cycle of reform beset by instability, uncertainty and fragmentation, which become features of both the process and outcome of the fragmented planning.

\section{Figure 1: Fragmentation and change in the English planning system}

\section{[Appended]}

We argue that, as the nature of planning requirements and the system itself has been shaped and revised, the role, position and knowledge bases of actors involved have shifted and, as a result, the assumptions and models deployed have altered. This brings into view important questions, which are poorly understood, concerning the types of knowledge and understanding that local planning officers actually need in this environment (see Davoudi and Pendlebury, 2010; Shaw and Lord, 2007; Taylor, 1999), and how a fragmentary planning system is navigated in practice.

\section{Governing fragmentary planning}

The remainder of this paper draws on findings from a research project into private sector inputs to local plan making in Southern England. The production of local plans is a statutory function of 
LPAs and are designed to provide a development vision for the area that is broadly representative of local interests. They must be evidence-based and are subject to scrutiny by a Planning Inspector. Sixteen local authority planning officers directly involved in local plan production were interviewed alongside 14 private consultants specialising in planning work. The semi-structured interviews revealed a wide range of tasks being undertaken by consultants. Table 1 offers a snapshot of the diversity of consultants active in planning, yet there are a number of differentiating characteristics, including size and specialisms offered, as well as more multidisciplinary firms, and diversification in client base. Consultant interviewees themselves were keen to stress the diversity in size, role and approach to public sector work: the larger planning consultancies typically offer a wide range of planning related services (e.g. Lichfields, Deloitte, AECOM) alongside smaller, specialist consultancies that operate within particular niches, performing bespoke tasks such as environmental and viability assessments. Such 'boutique' consultancies (Dotsch, 2016) such as Navigus, Maroon and Tibbalds have also more recently performed a number of roles in support of neighbourhood planning.

Table 1: Local Plan Input - exemplar consultant activity in Southern England

\begin{tabular}{|l|c|l|}
\hline \multicolumn{1}{|c|}{ Consultant tasks in local plan production } & $\begin{array}{c}\text { Frequency } \\
(\mathbf{n = 1 6 )}\end{array}$ & \multicolumn{1}{|c|}{ Consultancy Examples } \\
\hline Viability Appraisal & 5 & Adams Integra, Three Dragons \\
\hline Housing Assessment & 5 & Atkins, Halcrow \\
\hline Transport Study & 5 & Hankinson Duckett, CBA \\
\hline Landscape / Greenbelt Review & 5 & ORS, Forest Bus \\
\hline Gypsy and Traveller Site Assessments & 4 & Urban Edge, EPR \\
\hline Biodiversity Assessment & 3 & GVA, DTZ \\
\hline Retail Assessment & 3 & NLP, BE Group \\
\hline Employment Land Study & 3 & PBA, EPR \\
\hline Flood Risk Assessment & 3 & AECOM, URS \\
\hline Sustainability Appraisal & 3 & Hardisty Jones, Regeneris \\
\hline $\begin{array}{l}\text { Economic Evidence Base / Employment } \\
\text { Assessment }\end{array}$ & $\begin{array}{l}\text { n.b. for the purposes of illustration here and we have only included examples where the type of work } \\
\text { featured in more than one local plan. Consultancy names were correct at the time the work was } \\
\text { undertaken. }\end{array}$ & \\
\hline
\end{tabular}


The system change explained in Figure 1 has created new and/or additional tasks that are not easily serviceable by existing resources and therefore require new outlets or 'solutions'. The rise of the private sector within this fragmentary planning is therefore not only a question of scale and capacity, but also of the shifting nature of work undertaken and types of organisation now operating in planning. Crucially, the prevailing view from the LPAs interviewees was that private sector inputs into plan-making were critical to the production of the plan. The drive for solutions has been intensified by reforms placing new demands on planning departments (see for example Raco, 2018), and political pressure to complete local plans (MHCLG, 2018b), as recognised by both public and private interviewees:

... the challenge they [the LPA] face though is the never ending changes to the planning system particularly on the Local Plan side of things - they do chase their tails a bit, but also I think you find that a lot of it, there's plenty of reports and things about local plans not going through [examination by the Planning Inspectorate], that you ultimately feel some sympathy for them, but there are times through that plan making process where LAs clearly have not listened to advice that has been given by planning consultants and carry on regardless. (Consultant interview B)

This highlights the cycles of change illustrated in Figure 1 but also reveals the framing of consultants as advisors, albeit ones that may not always be listened to. Table 2 summarises the drivers and context in which consultant inputs have played out since 2010. Drawing on rationales discussed by interviewees, this seeks to show how upstream (political) factors such as austerity or the desire to speed up planning translate to local planning practice.

Table 2: Factors influencing planning consultant use across the public sector in England

\begin{tabular}{|l|l|}
\hline \multicolumn{1}{|c|}{ Upstream drivers } & \multicolumn{1}{|c|}{ Local planning 'realities' } \\
\hline $\begin{array}{l}\text { Austerity - an ideological desire for smaller } \\
\text { (local) state (but also coloured by neoliberal } \\
\text { watch-words such as market-orientated and } \\
\text { pro-growth). }\end{array}$ & $\begin{array}{l}\text { Pressure to provide cost-efficiency and reduce } \\
\text { overall expenditure - resulting in lack of in house } \\
\text { capacity, skills and institutional memory, and } \\
\text { precipitating external inputs. }\end{array}$ \\
\hline $\begin{array}{l}\text { Speed - generalised and longstanding } \\
\text { desire to 'speed up' planning and reduce } \\
\text { delay. }\end{array}$ & $\begin{array}{l}\text { Requirement to meet enforced timescales - } \\
\text { leading to the prioritising of statutory functions, } \\
\text { need for 'timely' responses, act as a driver for } \\
\text { outsourcing functions such as development } \\
\text { management and elements of plan production. }\end{array}$ \\
\hline $\begin{array}{l}\text { Quality - as above, a widespread (though } \\
\text { often uncritical) desire to improve the } \\
\text { perceived quality of plans, evidence and } \\
\text { decisions. }\end{array}$ & $\begin{array}{l}\text { Pressure to improve policy creation (e.g. shore- } \\
\text { up evidence) and decision-making (e.g. reduce } \\
\text { number of planning appeals) whilst reducing } \\
\text { spending (typically leading to private sector } \\
\text { inputs). Also undermines perceived competency } \\
\text { of LPAs, especially in terms technical, specialist } \\
\text { skills and expertise. }\end{array}$ \\
\hline $\begin{array}{l}\text { Certainty - linked to the desire for speed, } \\
\text { increasing credibility within the planning } \\
\text { system is seen as central to reducing } \\
\text { uncertainty and risk for developers. }\end{array}$ & \multicolumn{2}{|l}{} \\
\hline
\end{tabular}


Scrutiny - linked to the desire for quality, external (i.e. non-public) is increasingly regarded as fundamental to ensuring quality, legality, conformity.
Pressure for perceived independence, critical distance and outsider status (as well as knowledge mediators) necessitates involvement of non-state actors.

Despite upstream factors being exogenous to local planning (in the sense that they are centrallydriven and top-down choices), the subsequent realities faced by LPAs are typically presented as endogenous to local, 'public' planning. In this way, political choices can be framed as unavoidable local realities requiring hard, pragmatic choices, denying the agency of LPAs. One consequence of this process is that, in line with the 'entrepreneurial turn' in local government (Raco, 2018), many LPAs are now tasked with being cost neutral (i.e. subsidising the cost of running planning departments via income generation). Therefore, for those looking to reform internal processes and procedures - including staffing levels - the economic and political rationalities of austerity (and corresponding scarcity of government resources) can be used as a justification in order to aid cuts to budget areas that require on-going expenditure commitment, require redesign and which may produce more flexible solutions.

This context is somewhat different to the environment of change discussed by Shaw and Lord (2007) in respect to New Labour reforms. A further contextual factor here relates to the adoption of 'specialisms' in place of the so-called 'generalist planner' (Healey, 1985; Faludi, 1978) and implies a need for different kinds of knowledge and skillsets in planning (cf. Egan, 2004; Taylor Review, 2012) as well as culture change (Shaw and Lord, 2007; Grange, 2014). The expansion and diversification of work undertaken under fragmentary planning's growing ambit has, as such, encouraged the growth of a wide range of consultancies, reaching into numerous contributory disciplines (e.g. landscape, ecology, heritage, archaeology, environmental assessment and real estate development).

Consultants at all scales of activity act as 'solutionists' in a number of ways: they advise and service client needs, specifically they may take on services, but more commonly they conduct research and submit evidence, create masterplans, provide one-off specialist knowledge inputs and act as (notionally) impartial agents. Beyond planning, there is a wider literature on consultancy use in public services (e.g. Hood and Jackson, 1991; Saint-Martin, 1998; McCann, 2001; Prince, 2012; Linovski, 2015; Loh and Norton, 2015) which demonstrates that the roles which consultants perform are wide-ranging, but that even across professions and disciplines, there are commonalities in both the types of tasks performed and the rationale for, or legitimacy ascribed to, these activities. A common descriptor across consultancy types is a discursive focus on solutions: a vision statement from the planning consultancy WYG is quite typical: "we provide 
bespoke solutions, making our clients' ambitions possible" (WYG, 2017: no pagination). The emphasis on the breadth and scale of its 1,600 multi-disciplinary specialists differs markedly from many of the smaller firms - which tend to highlight the specialised, targeted or in-depth nature of their knowledge and services, while the WYG phrasing seeks to demonstrate both the breadth and depth of its 'offer'. A small consultancy example is Navigus planning who claim a progressive orientation "Navigus is planning for change that achieves social justice" (Navigus, 2018: no pagination).

The RTPI's $(2014 ; 2017)$ membership profile has also morphed to reflect the growth of the private sector and the changing nature of the public sector, with nearly half of all its chartered planners not working in the public sector by 2013 a statistic reinforced in the 2017 member survey which shows a diverse mix of self-identification across public, private and third sector divisions. For context, the proportion of the RTPI's membership working in the private sector hovered around $20 \%$ for the majority of the postwar period, before increasing significantly around the turn of century. The RTPI's (2016b) directory of planning consultants, although not necessarily comprehensive, stood at 465 consultancy firms operating in the UK in 2016. More widely the rise of planning consultancies runs parallel to the drop in the number of people employed in local government in the UK, which has fallen to a record low of 2.2 million (ONS, 2017) and selfemployed consultants, including planners, totalled 55,000 by 2017 (ibid.).

Benchmark figures are harder to come by, although Planning Resource's (2017) annual consultancy survey shows consistent year on year growth in turnover and staff levels, particularly for leading consultancies between 1996 and 2016. For instance, Arup, an independent firm of designers, planners, engineers, consultants and technical specialists offering a broad range of services, earned more than $£ 70.9 \mathrm{~m}$ in planning fee income in England in 2015/16, a figure which increased by $23.3 \%$ to $£ 92.5 \mathrm{~m}$ in $2016 / 17$ (Planning Resource, 2017). However, while global, multi-disciplinary consultancy firms might share some characteristics with the 'Big 10' that tend to dominate academic analyses of consultancies more widely, other significant players in the planning sector are far less well known. These tend to be more specialist planning firms that employ a higher number of chartered planners as an overall proportion of staff. While big players in the planning and development sector, these consultancies operate on a different level to the global firms discussed. What this picture demonstrates is a relative shift in capacity relative to the public sector, as well as an expansion of services and specialisms in the private sector. This process is in motion, however, as numerous takeovers/mergers and new firms feature, and this is an indicator of growth (i.e. commerciality of planning consultancy services), and the measurement of change is made more challenging. For example the planning consultancy Scott Wilson (employing approximately 5,000 staff) was taken over by URS in 2010 (employing approximately 
50,000 staff) and URS was then absorbed by the global firm AECOM in 2014 (who employed over 87,000 staff in 2017).

Planning consultants of course also work directly for developers and other private sector clients. This accounts for the marked growth of consultants in planning and means that the scale of involvement of the private sector across all aspects of governance, management, regulation and implementation of planning is unprecedented (Parker et al., 2014; Davoudi and Madanipour, 2015). This dual role also presents potential conflicts of interest, a concern that consultants themselves recognised as part of the re-framing of traditional public/private relations:

... where we provide development control advice to the local authority, we review their planning applications on a one-off basis as well as taking small strategic planning work from them. We still work for developers of residential and other sites ... we just do that very consciously and with agreement from all parties. So, sometimes that can be about setting up 'Chinese walls' within our own business so that there is no sharing of information or team members between those two different projects. Those were the kind of tools that most people are happy with us using. We also consciously take forward work for the developer and the local authority together, to actually give benefits to both sides. Because there is no need for that to be an adversarial relationship. There actually can be a lot of gains, both financial and timescale and all sorts of things in terms of actually working together. (Consultant interview A)

There may be further issues of a priori vs a posteriori setting of goals and policies and therefore about where to get the 'best' (fitting) advice and/or more malleable advice from either the professional or political perspective; as has been recognised in the wider literature on politics and planning over time (e.g. Altshuler, 1965; Flyvbjerg, 1998; Campbell and Marshall, 2000; Hillier, 2003). Moreover, the private sector has begun to sustain the discipline "despite the ambiguous nature of its knowledge base" (Brown et al., 2003: 339), and this co-managed approach is being widely endorsed, for example, given how public/private cooperation is expressed in recent RTPI output, which is increasingly the product of cross-sectoral partnerships itself (see RTPI, 2015).

The ability to draw in a wide range of evidence can act to alter the role of the planner and the exercise or maintenance of power in their own local authority. This rather depends on how the work is commissioned, overseen, absorbed and deployed, and in line with the arguments made by Shaw and Lord (2007), much of this can be considered as part of how planning cultures are influenced. As such there is a need to consider not only what is being done and why but who exactly and moreover how such work is being performed. The way that expertise and 'blackboxed' knowledge is applied (let alone how it is reified) raises questions of transparency and accountability too, as Raco et al. (2016: 218) note, consultants and other experts operate in "liminal governance spaces between private markets and the formal planning system" and in a system that, despite controversies and ambiguities surrounding the concept, continues to hold the 
notion of public interest central to its operation. How this is understood and maintained in practice is contestable of course and has spawned its own literature (for example; Tait, 2016; Bollens, 2002; Campbell and Marshall, 2002; Alexander, 2002; Innes, 1996). Indeed writing almost 30 years ago, Fordham (1990: 247) was critical of the increasingly blurred lines between the private and public sectors when it came to serving the public interest. He argued that "planning consultants cannot serve two masters", highlighting the possible conflict in consultants being employed by both the private and public sectors and contending that "if a consultant were to perform well for a local authority at the expense of a developer the news would quickly get around and such a consultant would rapidly lose his/her private sector clients" (ibid).

The implications of conflicts of interest and carrying over of practices for private clients to public sector clients is a central motivation for research in this area. The influence of market considerations in planning decisions has become more apparent over time, and highlights how particular specialisms are intrinsically the preserve of small 'expert' groups. The practices surrounding development viability appraisals are a useful case in point and are patrolled by real estate professionals (Kimelberg, 2011; Christophers, 2014; McAllister et al., 2016). Fordham (1990: 244) also highlighted that the use of consultant input was already seen by many LPAs as an essential, even routine part of modern planning, despite the impact it may have on their capacity for, and autonomy over, decision-making:

... by depending on a consultant's advice ... the Local Authority is abdicating responsibility for a significant part of a public decision ... there is in many cases no possibility of avoiding such delegation: the question is not whether but how to do it.

How such performativities involve techniques that contribute to the efficient operation of the state should be of interest to planning scholars. It is conceivable that these private inputs contribute to maintaining internal cohesion and legitimation of the state, or can conversely act to erode that status. This provides a further strand of necessary research endeavour to better understand this and the implications for practice as well as planning legitimacy. When it comes to professional conduct, the RTPI's (2016a) code of conduct, which is applicable to all chartered planners, serves as a means to structure professional behaviour and exhorts chartered planners to adhere to five core principles, namely: i. competence; ii. honesty and integrity; iii. independent professional judgement; iv. due care and diligence; and v. equality and respect as deemed appropriate professional behaviour. It stands to reason that policing this in practice (in whatever manner) and overseeing this in relation to private/public practice becomes even more challenging in a fragmented planning given the limited resources and information at the disposal of the RTPI. 


\section{Conclusions and Further Research}

The rise of the private sector in the fragmentary planning system that has emerged in England, presents some significant questions that require a critical perspective. We contend that it is vital that planning scholars reflect on the governance arrangements for planning that were constructed when it was a largely public sector activity (with a considerably narrower focus), and then unpick how the planning system is governed and regulated in the emergent circumstances outlined. The literature and emerging findings explored here have noted the growing number of private sector consultant inputs to the practice of planning which sit alongside neoliberalised governance arrangements and, while more empirical evidence is required, our work highlights some of the tensions that have grown. The period that appears critical is post-1990, marked as it is by a diversification and specialisation of planning responsibilities, and which features sustained policy and institutional change. A shorter time frame, in England at least, would be from 2004 onwards when the first major planning reforms from New Labour were introduced. These together have produced a fragmentary set of planning-related activities (Davoudi and Pendlebury, 2010) in a context of near permanent reform that are increasingly serviced by either private sector planning consultants or by non-planners who are drawing upon expertise located in a range of fields including surveying, ecology and economics. While this is itself not new, the range and scale of tasks within this fragmentary planning requiring these kinds of inputs is of a greater magnitude. Moreover, while our research suggests that LPAs retain a commissioning role over consultants, the upstream drives and local realists, are such that the ability to have oversight of the wider goal(s) of planning, is potentially curtailed.

Although planning scholars have begun to investigate this role of the private sector in planning, there appears to be little acknowledgement from within the planning profession as to the scale and significance of this shift, its possible implications, and the ways in which the cycle of reform affects on-going practice. We hypothesise that such trends may be undermining the oversight and integrity of the planning system - a system which requires synoptic thinking and understandings in order to produce coordinated spatial plans across topics and boundaries (Tewdwr-Jones, 2012). In such a situation, individual inputs may well be of high quality and it may also be that the knowledge required 'only' resides with private sector consultants. However, it seems likely that the compartmentalisation of planning into a series of discrete and deliverable elements (i.e. one dimension of fragmentation) replicates private sector project management structures. This opens up the planning process to inputs from a range of private companies whose expertise is sold on the basis that it is directly targeted towards achieving specific outcomes (solutionism) and meeting particular client needs (see Davies and MacKenzie, 2014). Thus, what is less clear is where immediate and latent (dis-)advantages lie given the opening-up and repositioning of public and 
private sector planners. So, alongside expressions of privatisation, the marketisation of the public sector carries not only possible financial implications for the public purse, but quite conceivably a more mixed set of outcomes (e.g. when assessing cost savings in terms of the orientation or basis of consultant derived data and its deployment).

These implications have yet to be fully explored in the literature and even less so by empirical planning studies. The initial discussion here and which is developing elsewhere (see Raco and Savini, 2018) indicates that there are likely to be other rationalities and drivers introduced that explain the behaviours of resource-holders and decision makers in planning that are also worthy of exploration. We can additionally postulate that the 'mongrelisation' of planning activities (Sandercock, 2004) across sectors provides a means to cross-fertilise ideas, cultures, assumptions and practices between clients and contractors and between and across publicprivate/private-private relations. Indeed the mixed client base of many consultants may be acting to shift the modalities of planning work and the models drawn in and accepted as part of the doxa of planning practice. That is to say how the work is performed and on what basis, particularly given that it has been claimed that consultants are likely to be influenced by client interest. This is an issue which is further complicated when public authorities are both clients with their own interests, as well as maintaining the public interest on behalf of their constituents. It may well also be that the use of the private sector acts to disempower local government while maintaining control at a distance for central government - as per the NPM thesis that technologies can act to centralise control. This is a point also found in the wider policy studies literature (see Diefenbach, 2009; Christensen and Laegreid, 2007; Laegreid and Christensen, 2013) and the planning literature (see Clifford and Tewdwr-Jones, 2013).

It is useful therefore to direct questions towards LPAs (and the local politicians they ultimately serve) about how the inputs provided by consultants are actually understood, absorbed and deployed. For example, we may ask what degree of influence or control consultants have on outcomes, and what agency do they exert on local public sector planners and elected politicians? It may be that some consultants are less obviously affected - but affected nonetheless - or that they introduce new forms of knowledge that may confound local politicians and public sector officials. A more nuanced understanding of the way that consultants are employed and operate is necessary, before articulating any conclusions about their influence and how to judge the outcomes in principle and in practice. Such a process of inquiry should include: setting out more clearly the range of consultants; clarifying the extent of the tasks undertaken; stipulating the basis for their use and how their inputs are both co-created and deployed; and exploring how the three roles set out above act to perform modes of planning in different settings. 
We propose the framework for research below as a starting point that links questions of what, why, how and by whom such work is performed, to the need for theoretically-led, critical perspectives considering the rationalities underpinning fragmentary planning. This list does not claim to be comprehensive, nor explicit about the approaches to be pursued, but seeks to highlight avenues for investigation which appear to us to merit attention across four central themes:

1. To explore the explicit and implicit rationalities which underpin the use of private planning consultancies - exploring the rationales and motives (on both sides), the skills and expertise provided, and the way that subsequent inputs are negotiated, packaged and employed;

2. To develop a closer understanding of the activity and roles of on-going practices (including types and range of actions, timing, alternatives, the commissioning process, brief-writing, resultant contracts etc.) - viewed in terms of power dynamics, balance of risk and purported benefits (regarding discrete inputs but also wider working arrangements) and also the function of the inputs performed by the private sector;

3. To map and examine the outcomes and effects of private sector inputs - in terms of the form and application of private sector work, as well as the implementation or other uses and influence of private sector inputs; and by extension, to:

4. Critically engage with newly emerging governance arrangements, particularly regarding accountability and the public interest, including: the stated aims of central and local government, oversight (in terms of quality control but also working arrangements), control between and amongst LPAs and consultants - and between central government, developers and communities.

We anticipate that the pursuit of these themes will be central to uncovering a fragmentary planning system that may be producing inefficiencies as opposed to synergies, with the fragmented inputs, variable understandings and opacity of its practices, producing a planning system that is less than the sum of its parts. That is not to say that such a transfer of power to consultants could or should not be in the public interest but that, as yet, we know far too little about this to make such an assessment.

\section{References}

Allmendinger, P. and Haughton, G. (2013) 'The evolution and trajectories of English spatial governance: 'Neoliberal' episodes in planning', Planning Practice \& Research, 28(1): 6-26.

Allmendinger, P. and Haughton, G. (2015) 'Post-political regimes in English planning' in Metzger, J., Allmendinger, P. and Oosterlynck, S. (eds.) Planning Against the Political: Democratic Deficits in European Territorial Governance, London: Routledge, pp.29-54

Alexander, E. (2002) 'The public interest in planning: from legitimation to substantive plan evaluation', Planning Theory, 1(3): 226-249.

Altshuler, A. (1965) The City Planning Process: A Political Analysis, Ithaca, New York: Cornell University Press. 
Ascher, K. (1987) The politics of privatisation, Basingstoke: Macmillan.

Barnett, C. (2005) 'The consolations of neoliberalism', Geoforum, 36: 7-12.

Bollens, S. (2002) 'Urban Planning and Intergroup Conflict: Confronting a Fractured Public Interest', Journal of the American Planning Association, 68(1): 22-42.

Brown, C., Claydon, J. and Nadin, V. (2003) 'The RTPI's Education Commission: context and challenges', Town Planning Review, 74(3): 333-45.

Campbell, H. and Marshall, R. (2000) 'Moral Obligations, Planning, and the Public Interest: A Commentary on Current British Practice', Environment and Planning 'B', 27(2): 297-312.

Campbell, H. and Marshall, R. (2002) 'Utilitarianism's Bad Breath? A Re-Evaluation of the Public Interest Justification for Planning', Planning Theory, 1(2): 163-187.

Christophers, B. (2014) 'Wild Dragons in the City: Urban political economy, affordable housing development and the performative world-making of economic models', IJURR, 38(1): 79-97.

Christensen, T. and Laegreid, P. (2007) 'The whole-of-government approach to public sector reform'. Public Administration Review, 67(6): 1059-1066.

Clifford, B. (2016) 'Clock-watching and box-ticking': British local authority planners, professionalism and performance targets', Planning Practice \& Research, 31(4): 383-401.

Clifford, B., Ferm, J., Livingstone, N. and Canelas, P. (2018) Assessing the impacts of extending permitted development rights to office-to-residential change of use in England, RICS Research Report, London: RICS.

Clifford, B. and Tewdwr-Jones, M. (2013) The Collaborating Planner?, Bristol: Policy Press.

Committee of Public Accounts (2007) Central Government's Use of Consultants, 31st Report, House of Commons, Session 2006-07 HC309, London: HMSO.

Corburn, J. (2003) 'Bringing Local Knowledge into Environmental Decision Making: Improving Urban Planning for Communities at Risk', Journal of Planning Education and Research, 22(4): 420-433.

Davies, A. and Mackenzie, I. (2014) 'Project complexity and systems integration: constructing the London 2012 Olympics and Paralympics Games', International Journal of Project Management, 32: 773-790.

Davoudi, S. (2006) ‘Evidence-Based Planning', disP - The Planning Review, 42(165): 14-24.

Davoudi, S. and Healey, P. (1990) Using Planning Consultants: The Experience of Tyne and Wear Development Corporation, Urban Regeneration and the Development Process, Project Paper Series No. 2, Newcastle: University of Newcastle Upon Tyne.

Davoudi, S. and Madanipour, A. (eds.) (2015) Reconsidering Localism, London: Routledge.

Davoudi, S. and Pendlebury, J. (2010) 'The evolution of planning as an academic discipline', Town Planning Review, 81(6): 613-645.

DCLG (2012) [Department of Communities and Local Government] National Planning Policy Framework, London: DCLG.

Diefenbach, T. (2009) 'New public management in public sector organizations: the dark sides of managerialistic 'enlightenment", Public Administration, 87(4): 892-909. 
Dotsch, J. (2016) 'From Solution Shop to Boutique Consulting? Capturing Recent Developments on the German Consulting Market', Management Dynamics in the Knowledge Economy, 4(2): 291-306.

Egan Review (2004) Report of the Egan Review of Skills for Sustainable Communities, London: ODPM.

Evans, B. (1995) Experts and Environmental Planning, Aldershot: Averbury.

Faludi, A. (1978) Essays on Planning Theory and Education, Oxford: Pergamon.

Flyvbjerg, B. (1998) Rationality and power: Democracy in practice. Chicago: University of Chicago Press.

Fordham, R. (1990) 'Planning consultancy: can it serve the public interest?', Public Administration, 68: 243-248.

Grange, K. (2014) 'In search of radical democracy: the ideological character of current political advocacies for culture change in planning', Environment and Planning A, 46(11): 2670-2685.

Gunn, S. (2018) 'Planning professionalism in the new technocracy - Ethics, values and practices', in Raco, M. and Savini, F. (eds.) Planning and Knowledge: How New Forms of Technocracy are Shaping Contemporary Cities. Bristol, Policy Press.

Gunn, S. and Vigar, G. (2012) 'Reform processes and discretionary acting space in English planning practice, 1997-2010', Town Planning Review, 83(5): 533-552.

Haughton, G., Allmendinger, P., Counsell, D. and Vigar, G. (2009) The New Spatial Planning Territorial Management with Soft Spaces and Fuzzy Boundaries, London: Routledge.

Healey, P. (1985) 'The Professionalisation of Planning in Britain', Town Planning Review, 56(4): 492-507.

Higgins, M. and Allmendinger, P. (1999) 'The changing nature of public planning practice under the New Right: the legacies and implications of ', Planning Practice and Research, 14(1): 39-67.

Hillier, J. (2003) Shadows of Power. An Allegory of Prudence in Land-Use Planning, London: Routledge.

Hood, C. and Jackson, M. (1991) Administrative Arguments, Aldershot: Dartmouth.

Kimelberg, S. (2011) 'Inside the Growth Machine: real estate professionals on the perceived challenges of urban development', City and Community, 10(1): 76-99.

Innes, J. (1996) 'Planning through consensus building: A new view of the comprehensive planning ideal', Journal of the American Planning Association, 62(4): 460-472.

Laegreid, P. and Christensen, T. (eds.) (2013) Transcending new public management: the transformation of public sector reforms, Aldershot: Ashgate.

Lapsley, I. (2009) 'New Public Management: The Cruellest Invention of the Human Spirit?', ABACUS, 45(1): 1-21.

Linovski, O. (2015) 'Politics of Expertise: Constructing Professional Design Knowledge in the Public and Private Sectors', Journal of Planning Education and Research, 36(4): 1-14.

Linovski, O. (2018) 'Shifting Agendas: Private Consultants and Public Planning Policy', Urban Affairs Review, First published 6 February, 2018 online. 
Loh, C. and Norton, R. (2013) ‘Planning Consultants and Local Planning', Journal of the American Planning Association, 79(2): 138-147.

Loh, C. and Norton, R. (2015) 'The Impact of Planning Consultants on the Policy Content of Local Master Plans', Journal of Planning Education and Research, 35(2): 199-208.

Lord, A. and Tewdwr-Jones, M. (2014) 'Is Planning "Under Attack"? Chronicling the deregulation of urban and environmental planning in England', European Planning Studies, 22(2): 345-361.

MacDonald, K., Sanyal, B., Silver, M., Ng, M., Head, P., Williams, K., Watson, V. and Campbell, $\mathrm{H}$. (2014) 'Challenging theory: Changing practice: Critical perspectives on the past and potential of professional planning'. Planning Theory \& Practice, 15(1): 95-122.

McAllister, P., Street, E. and Wyatt, P. (2016) 'Governing calculative practices: An investigation of development viability modelling in the English planning system'. Urban Studies, 53(11): 23632379.

McCann, E. (2001) 'Collaborative Visioning or Urban Planning as Therapy? The Politics of PublicPrivate Policy Making', Professional Geographer, 53(2): 207-218.

MHCLG [Ministry of Housing, Communities and Local Government] (2018a) Revised National Planning Policy Framework, 24 July 2018, London: MHCLG.

MHCLG (2018b) Local Plan intervention: letters to councils, 23 March 2018. https://www.gov.uk/government/publications/local-plan-intervention-letters-to-councils (accessed: 24/09/18).

NAO [National Audit Office] (2014) Financial sustainability of local authorities, London: NAO.

Navigus (2018) Navigus planning website http://navigusplanning.co.uk/ (accessed: 26/06/2018).

ONS [Office of National Statistics] (2016) Statistical bulletin: Public sector employment, UK: June 2017.

https://www.ons.gov.uk/employmentandlabourmarket/peopleinwork/publicsectorpersonnel/bullet ins/publicsectoremployment/june2017 (accessed: 25/09/17).

Parker, G., Street, E., Raco, M. and Freire-Trigo, S. (2014) 'In Planning We Trust?', Town and Country Planning, 83(12): 537-540.

Parker, G., Lynn, T. and Wargent, M. (2015) 'Sticking to the script? The co-production of neighbourhood planning in England', Town Planning Review, 86(5): 519-536.

Parker, G., Lynn, T. and Wargent, M. (2017) 'Contestation and conservatism in neighbourhood planning in England: reconciling agonism and collaboration?', Planning Theory and Practice, 17(3): 446-465.

Parker, G., Salter, K. and Hickman, H. (2016) 'Caution: Examinations in progress. The operation of neighbourhood plan examinations in England', Town and Country Planning, 85(12): 516-522.

Parker, G., Street, E. and Wargent, M. (2018) 'Advocates, Advisors and Scrutineers: the technocracies of private sector planning in England', in Raco, M. and Savini, F. (eds.) Planning and Knowledge: How New Forms of Technocracy are Shaping Contemporary Cities, Bristol, Policy Press.

Planning Advisory Service [PAS] (2014) 'Outsourcing planning policy - the Barnet experience', Nick Lynch, PAS Presentation 4th February 2014. 
Planning Resource (2016) 'The Planning Consultancy Survey 2016'. http://offlinehbpl.hbpl.co.uk/NewsAttachments/RLP/consurveynew.pdf (accessed: 24/09/18).

Planning Resource (2017) 'The Planning Consultancy Survey 2017'. http://offlinehbpl.hbpl.co.uk/NewsAttachments/RLP/PLN PCS 2017 Online.pdf $\quad$ (accessed: 24/09/18).

Prince, R. (2012) 'Policy transfer, consultants and the geographies of governance', Progress in Human Geography, 36(2): 188-203.

Raco, M. (2013) 'The new contractualism, the privatisation of the welfare state, and the barriers to open source planning'. Planning Practice \& Research, 28(1): 45-64.

Raco, M. (2018) 'Private consultants, planning reform, and the marketisation of local government finance', in Ferm, J. and Tomaney, J. (eds.) Planning Practice: Critical Perspectives from the UK, London: Routledge, pp.123-137.

Raco, M. and Savini, F. (eds) (2018) Planning and Knowledge: How New Forms of Technocracy are Shaping Contemporary Cities, Bristol: Policy Press.

Raco, M., Street, E. and Freire-Trigo, S. (2013) 'Privatising Democracy? The Transformation of Local State-Market Relations in Urban Governance,' paper presented 26 June 2013 to ICPP 2013 1st International Conference on Public Policy, Grenoble, France.

Raco, M., Street, E. and Freire-Trigo, S. (2016) 'The New Localism, Anti-Political Development Machines, and the Role of Planning Consultants: Lessons from London's South Bank', Territory, Politics, Governance, 4(2): 216-240.

Remoy, H. and Street, E. (2016) 'The dynamics of "post-crisis" spatial planning: A comparative study of office conversion policies in England and The Netherlands', Land Use Policy, 77: 811820.

RTPI [Royal Town Planning Institute] (2014) RTPI Member Survey 2013. RTPI Research Report No.3, March 2014, London: RTPI.

RTPI (2015) Investing in Delivery: How we can respond to the pressures on local authority planning?, Research RTPI Research Report No. 10 October 2015, London: RTPI.

RTPI (2016a) RTPI Code of Professional Conduct. Located at: http://www.rtpi.org.uk/media/2684840/code_of_conduct_newcover2017.pdf $\quad$ (accessed: 24/09/18).

RTPI (2016b) Directory of Consultants. https://www.rtpiconsultants.co.uk (accessed: 12/07/16).

RTPI (2017) RTPI Insight - Member Survey 2017, The Planner, December 2017, pp.26-29

Saint-Martin, D. (1998) 'The new managerialism and the policy influence of consultants in government: an historical-institutionalist analysis of Britain, Canada and France', Governance, 11(3): 319-356.

Sandercock, L. (2004) 'Towards a Planning Imagination for the 21st Century', Journal of the American Planning Association, 70(2): 133-141.

Shaw, D. and Lord, A. (2007) 'The cultural turn? Culture change and what it means for spatial planning in England', Planning Practice and Research, 22(1): 63-78. 
Tait, M. (2016) 'Planning and the public interest: Still a relevant concept for planners?', Planning Theory, 15(4): 335-343.

Taylor, N. (1999) 'Anglo-American town planning theory since 1945: three significant developments but no paradigm shifts' Planning Perspectives, 14(4): 327-345.

Taylor Review (2012) Report of the Taylor Review of Planning Guidance, London: DCLG.

Tewdwr-Jones, M. (2012) Spatial planning and governance: Understanding UK planning, Basingstoke: Palgrave Macmillan.

Thornley, A. (1993) Urban planning under Thatcherism, London: Routledge.

Watson, V. (2014) 'Co-production and collaboration in planning. The difference', Planning Theory and Practice, 15(1): 62-76.

WYG consultancy (2018) WYG website https://www.wygcareers.com/our-business (accessed: 24/09/18). 
Figure 1: Fragmentation and change in the English planning system

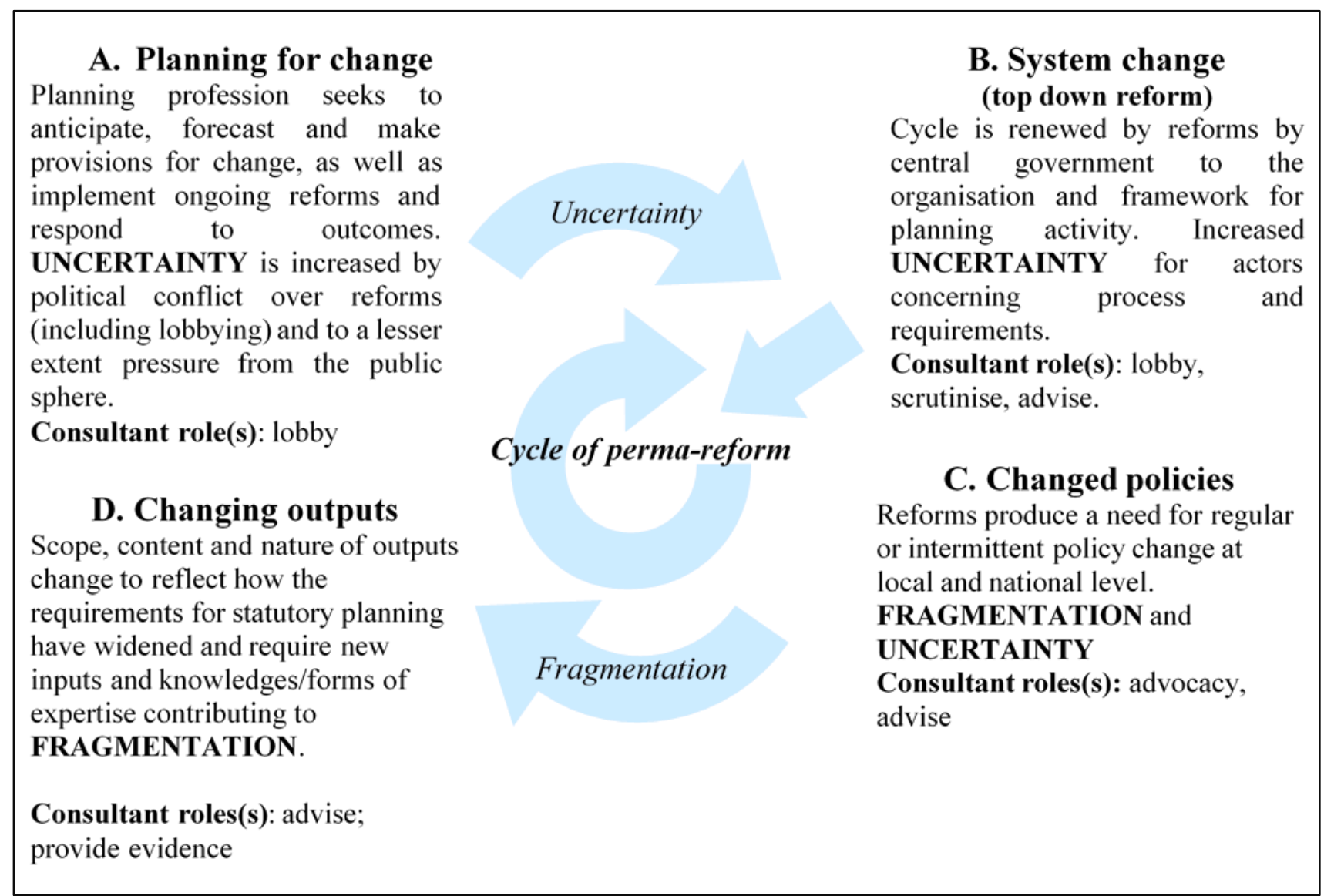

